\title{
Resisting Agamben: The biopolitics of shame and humiliation
}

Philosophy and Social Criticism $000(00)|-2|$

(c) The Author(s) 201I

Reprints and permission: sagepub.co.uk/journalsPermission.nav DOI: I0.1|77/019|4537||42I604

psc.sagepub.com

\author{
Lisa Guenther \\ Vanderbilt University, Nashville, TN, USA
}

\begin{abstract}
In Remnants of Auschwitz, Giorgio Agamben argues that the hidden structure of subjectivity is shame. In shame, I am consigned to something that cannot be assumed, such that the very thing that makes me a subject also forces me to witness my own desubjectification. Agamben's ontological account of shame is inadequate insofar as it forecloses collective responsibility and collapses the distinction between shame and humiliation. By recontextualizing three of Agamben's sources - Primo Levi, Robert Antelme and Maurice Blanchot - I develop an alternative account of shame as the structure of intersubjectivity, and of a collective responsibility that is more fundamental than the subject itself. On this basis, I sketch the preliminary outline of a biopolitics of resistance rooted in the ethics of alterity. The intuition driving this approach is that life is never bare, that even in situations of extreme affliction there remains a relation to alterity which provides a starting point for resistance.
\end{abstract}

\section{Keywords}

Giorgio Agamben, Robert Antelme, Auschwitz, biopolitics, Maurice Blanchot, humiliation, shame

In his book, Remnants of Auschwitz (hereafter cited as $R A$ ), Giorgio Agamben argues that the hidden structure of subjectivity is shame. In shame, I am bound to something I can neither escape nor assume - be it language, physiological life, or even death - such that the very thing that makes me a subject also forces me to witness the limits, or even the dissolution, of my own subjectivity. For Agamben, 'shame is truly something like the hidden structure of all subjectivity and consciousness. Insofar as it consists solely in the event of enunciation, consciousness constitutively has the form of something that cannot be assumed. To be conscious means: to be consigned to something that cannot be assumed' (RA: 128). Rather than grounding his account of shame in a theory of the

\footnotetext{
Corresponding author:

Lisa Guenther, Vanderbilt University, Department of Philosophy, 229 Furman Hall, Nashville, TN 37240, USA

Email: lisa.n.guenther@gmail.com
} 
emotions or social norms, Agamben approaches shame as an ontological question concerning the subject's relation to its own being or non-being. His method of analysis works through association to draw out parallel structures in Holocaust testimonies (Levi, Bettelheim, Antelme), philosophical accounts of shame (early Levinas, Heidegger, Benjamin and Kerenyi), sadomasochistic desire, Kantian auto-affection, Spinozist self-reflexivity, the poetics of Keats, Bachmann and Rimbaud, the linguistics of Benveniste and Pessoa, the psycho-biology of Binswanger, and the psycho-ontology of Bin. What connects these widely divergent authors and texts is the common structure of shame, understood as the 'absolute concomitance of subjectification and desubjectification, self-loss and self-possession, servitude and sovereignty' (ibid.: 107).

This analysis of shame emerges in the context of Agamben's broader account of subjectivity as an impossible negotiation of bios and zoe, or biographical life and biological life. In texts such as Homo Sacer (1998; hereafter cited as HS), State of Exception (2005b) and The Open (2004), Agamben criticizes biopower for exploiting the gap between bios and zoe in order to produce sovereign power, which is invested with an exclusive authority to kill or let live, and 'bare life', which has been stripped of its bios and reduced to a 'life exposed to death' ( $H S$ : 88 ; see also $R A$ : 156). Bare life is no longer recognizable as specifically human, nor has it simply become animal; rather, it functions as a politicized form of disposable life, life that can be killed without murder or sacrifice. As such, it provides sovereign power with its ultimate object. In Homo Sacer, Agamben argues that sovereign power and bare life are not simply opposites; rather, they occupy together a 'zone of indistinction in which they can no longer be told apart' (HS: 96). In contemporary forms of biopower, this zone of indistinction is radically expanded, such that 'we are all virtually homines sacri', all exposed to a radical splitting from our own personal, biographical, specifically human life (ibid.: 115).

In Remnants of Auschwitz, Agamben extends his analysis of bare life to include as its privileged example the Muselmann: the death camp prisoner whose existence has been reduced to a kind of living death, or inhuman humanity $(R A: 44,48)$. Here, as in Homo Sacer, Agamben argues that the Muselmann, as a figure of bare life, enters a zone of indistinction or 'gray zone' with his own torturer: a zone where it becomes impossible to separate the torturers from the tortured. Here, too, Agamben argues that the Muselmann is not merely an extreme possibility of radical political exploitation; rather, we are all (virtually) Muselmanner, precisely because the structure of subjectivity is shame, or the double movement of subjectification and desubjectification. Some readers have criticized Agamben for blurring political, historical and ethical distinctions to the point where it becomes nearly impossible to explain meaningful differences between prisoners within the camps, many of whose experiences differed significantly from that of the Muselmann, or between death camps and work camps, or between prisoners and other biopolitical subjects, or even between prisoners and their torturers. ${ }^{1}$ Building on these critiques, I analyse the specific role that shame plays in Agamben's account of biopower, arguing that his ontological approach to shame effaces a crucial distinction between shame as a feeling of collective ethical responsibility, and humiliation as an instrument of political domination. It is one thing to be 'constitutionally divided on account of having become speaking beings' (ibid.: 129), and another thing to be humiliated as part of a project of extermination, to have this constitutive disjunction between life and 
language split apart and exploited. And it is yet another thing to feel an ethical shame what Primo Levi calls the shame of the 'just man' (cited ibid.: 87) - that such humiliations occur, whether or not they are inflicted upon oneself or by oneself.

In what follows, I distinguish between shame and humiliation, where the latter is not merely a more intense version of the former, but involves a fundamentally different structure. Humiliation works by singling out this or that person as deviant, out of place, abnormal, or bad, and displaying them before real or imagined others. Humiliation individuates; it isolates someone from all the others, not as a subject with agency and voice but as an object of scrutiny, scorn and possible violence. But this is an empty individuation; for even as it singles one out, humiliation negates one's singularity as this subject, distinct from everyone else but still within a social relation. The mechanism of individuation in humiliation singles one out as that rather than this; it marks one as that which does not belong, as that which must be expelled in order for the community to feel better. In this sense, humiliation works both to isolate the one who does not belong and to build a sense of unity and common identity among those who remain within the fold. The humiliated one is singled out as no one or nothing - but as a nothing which is visible, exposed for everyone to see, put on display as nothing of value - so that the humiliating subject can be someone. When humiliation is accomplished by marking someone's body, clothing, or dwelling, it stamps one with a visible and more or less permanent sign of this isolated, expelled identity, leaving no avenues of escape or return, no possibilities for becoming otherwise. The scarlet letter, the tattoo, the yellow star - all attest to an identification of the subject with his or her isolated fault. You are an adulteress, a criminal, a Jew: frozen in time, fixed in a position on the margins of social life where everyone can see you but no one will hear you, where you can neither leave nor stay, condemned to a living death.

Humiliation dehumanizes; it severs relations between one person or group and a larger community. But shame is not the same as humiliation. Shame also individuates the subject, but in a different way: not by singling one out for negation or exclusion, but by intensifying the ambiguity of an indissoluble relation to others. As Eve Kosofsky Sedgwick puts it, shame makes a 'double movement ... toward painful individuation, toward uncontrollable relationality' (2003: 37). What is unassumable in the feeling of shame is not an aspect of one's own being, but rather the relation to an other to whose gaze I am exposed, but whose view of myself I cannot control. The classic phenomenological analysis of shame comes from Sartre's Being and Nothingness. I am crouched at a keyhole, positioned as pure spectator, when suddenly I hear footsteps behind me in the hallway, and I feel myself exposed to the gaze of another. It matters little if this other is empirically there or not; the feeling of exposure introduces something irrevocable into my existence, a being-for-others that triangulates my self-relation and contests my position of mastery. Suddenly, I have an outside, an appearance which is mine but which nevertheless escapes my own grasp, a skin which is more immediately accessible to others than to myself. Sartre articulates the structure of shame not as a double movement of subjectification and desubjectification, but rather as a double relation to oneself and the Other: 'I am ashamed of myself before the Other' (2003: 296). Unlike humiliation, which simultaneously subjectifies and desubjectifies through an empty individuation which singles one out for annihilation, shame intersubjectifies; it attests to an irreducible 
relation to others in the midst of one's own self-relation. However painful shame may be, it confirms this relationality of the subject, and could not arise without it. As I will argue, even humiliation attests to relationality, if only indirectly, by addressing the one it seeks to annihilate, and by exploiting the relationality which makes this address possible.

In this article, I offer a reading of Agamben's account of shame in Remnants of Auschwitz alongside several of his own sources: Primo Levi, Robert Antelme and Maurice Blanchot. ${ }^{2}$ My aim is to show that Agamben's ontological account of shame is inadequate, primarily because it equates the structure of shame with the structure of humiliation, while overlooking the ethical and political dimensions of shame as an irreducible relation to the other. Rather than accepting Agamben's claim that shame is structured through a double movement of subjectification and desubjectification, I argue that shame highlights the structure of intersubjectivity, and ultimately of a collective responsibility that is more fundamental than the subject itself. By reading Levi, Antelme and Blanchot with and against Agamben, I sketch the preliminary outline of a biopolitics of resistance rooted in an ethics of alterity. This biopolitical resistance is disclosed in feelings of shame, and it is even indirectly or negatively disclosed in the experience of humiliation; but shame alone does not accomplish resistance. It provides only the starting point for a solidarity that traverses the distinction between bios and zoe towards a community of embodied, speaking subjects who have nothing in common but their irreducible relation to alterity.

\section{The shame of survival: Agamben and Primo Levi}

Agamben begins his discussion of shame with a passage from Primo Levi's book, The Reawakening, in which Levi reflects on the liberation of Auschwitz by Russian soldiers, and on the shame that seemed evident on the soldiers' faces as they witnessed the abject destitution of the prisoners:

\footnotetext{
They did not greet us, nor smile; they seemed oppressed, not only by pity but also by a confused restraint which sealed their mouths, and kept their eyes fastened on the funereal scene. It was the same shame which we knew so well, which submerged us after the selections, and every time we had to witness or undergo an outrage: the shame that the Germans never knew, the shame which the just man experiences when confronted by a crime committed by another, and he feels remorse because of its existence, because of its having been irrevocably introduced into the world of existing things, and because his will has proven nonexistent or feeble and was incapable of putting up a good defense. (Cited $R A$ : 87; see also Levi's own citation of this passage in The Drowned and the Saved, 1988: 72-3)
}

In this passage, shame circulates as an affect between the soldiers who come to liberate the camp and the prisoners who have both suffered and witnessed unimaginable atrocities. The only ones left unaffected by shame are the Germans who were guilty of either perpetrating or silently consenting to these atrocities. The feeling of shame does not turn on culpability here, but rather on a moral sensitivity to crimes against humanity. As such, it crosses the distance between those who could not possibly understand one another's experience, or even adequately articulate their own; it depends not on cognition or even 
recognition but rather on an affective response to violence and suffering in which those who have done nothing wrong - or have done everything right - feel immediately implicated.

Agamben reads this passage on shame in the context of Primo Levi's remarks on the 'gray zone' in which the 'long chain of conjunction between victim and executioner" comes loose, where the oppressed becomes oppressor and the executioner in turn becomes a victim' ( $R A$ : 21; Levi cited without pagination). Agamben praises Levi for having 'fearlessly entered into an absolutely unexplored territory of ethics' by identifying this gray zone, and he criticizes Levi's later reflections on survivor guilt and shame as a 'test of conscience so puerile that it leaves the reader uneasy' $(R A: 88)$. But Li's not clear that Levi ever meant by the 'gray zone' a zone of indistinction which effaces the difference between oppressor and oppressed, victim and executioner. He explicitly criticizes a film by Liliana Cavani for endorsing the view that 'we are all victims and murderers', and states in response, 'I do not know, and it does not much interest me to know, whether in my depths there lurks a murderer, but I do know that I was a guiltless victim and I was not a murderer' (Levi, 1988: 48). In the context of Levi's own discussion, the gray zone does not describe the logic of the camps as such, but rather those inhabitants of the camps who acted as Kapos or other figures between the prisoner and the guard. Why does Agamben find the gray zone so compelling, to the point of generalizing Levi's concept beyond its context, and why does he find survivor guilt so disturbing and pathetic?

Agamben is critical of shame as a feeling of responsibility for a crime that one did not personally commit, insisting rather on the importance of personal responsibility for crimes actually committed. ${ }^{3} \mathrm{He}$ characterizes collective guilt as a 'generic' solution to 'an ethical problem [that] cannot be mastered', a 'generalization of the accusation' that 'somehow blunts its edge' $(R A: 94,91)$. It is as if Agamben sees shame as a 'sham' form of guilt, too precious in those who did not personally do anything wrong, and too evasive in those who did (such as Fritz Stangl, discussed on ibid.: 97-8). In his own analysis of shame, Agamben seeks to move 'beyond good and evil' from the ethical register of innocence and guilt towards the ontological register of subjectification and desubjectification. He theorizes shame as an ontological affect proper to beings who have nothing in common but the impropriety of their own death, beings who are expropriated at the very moment that they appropriate themselves. ${ }^{4}$ In other words, shame is the affect of Heidegger's Being-towards-death, read through the lens of his later work on the event of Being which expropriates Dasein at the very moment of its appropriation. In a bizarre twist (which is not for that reason unusual in Agamben's work), Heidegger becomes more of an authority on shame in the Holocaust than Levi himself, the implication being that we need to read Levi through Heidegger in order to see past his puerile indulgence in survivor guilt and grasp the 'unthought' of Levi's own work.

But it is not logically or even politically necessary to choose between the legal prosecution of individual guilt and the ethical feeling of collective shame; indeed, I would argue that the latter is a necessary condition for the former. Agamben's rejection of survivor guilt overlooks an important distinction made by Bruno Bettelheim in the following passages, which Agamben himself quotes:

$[T]$ he real issue $\ldots$ is that the survivor as a thinking being knows very well that he is not guilty, as I, for one, know about myself, but that this does not change the fact that the 
humanity of such a person, as a feeling being, requires that he feel guilty, and he does. (Cited RA: 89)

Only the ability to feel guilty makes us human, particularly if, objectively seen, one is not guilty. (Cited ibid.: 93)

For Bettelheim, the capacity for shame - the capacity to feel guilty, even when one knows that one has done nothing wrong - is the mark of the human. ${ }^{5}$ What does 'humanity' mean in this context? Given the program of systematic dehumanization and extermination undertaken by the Nazis, humanity means the capacity to affirm one's relations to others even when everything has been calculated to sever these relations. The camps did not seek merely to kill, starve and torture Jews, but also to single them out as less than human, to strip them of all meaningful relationships, to shatter their physical, personal and interpersonal lives. To affirm one's irreducible relation to others even in the midst of such radical systematic destruction of relations constitutes an act of resistance, rather than capitulation, to the Nazi program.

The importance of shame in this context is its emphasis on relations rather than acts: I feel shame not because of what I have done, but rather because others matter to me, and because I care what they think of me. ${ }^{6}$ The capacity for shame attests to a remnant, however small, of interhuman relationality - an interest, however diminished or degraded, in others. This is why shame can function as a site of resistance, a feeling for justice even in the midst of radical injustice: because it confirms the root of responsibility in our relations with others. Even if it is physically impossible to make good on these responsibilities, and even if the ones who are actually guilty absolutely refuse to carry their burden of responsibility, the response of shame holds open the possibility that things could be otherwise, that there is still some trace of a meaningful ethical relation. While many survivors were haunted by painful feelings of guilt and shame, in ways that forbid the celebration of shame as an unambiguous sign of resistance and human dignity, Bettelheim gives us a way of understanding these feelings as something more than a "puerile' feeling of guilt over a stolen crust of bread, and even more than the traumatic identification with one's oppressors (see Leys, 2007: 17-55). As such, it provides one of the clues for an alternative analysis of shame, based on Agamben's own sources, as a feeling of intersubjectification rather than simultaneous subjectification and desubjectification.

In spite of Agamben's suspicions, there is nothing 'generic' about the collective responsibility to which the survivor's shame attests. Without the capacity to hold oneself responsible for acts committed by others, the politics of resistance to anti-Semitic, racist, sexist and other forms of domination would be confined to the prosecution of individual crimes committed by discrete subjects. But precisely because these systems of domination are structural rather than individual, the struggle against them presupposes some capacity - which Bettelheim here calls 'human' - to feel implicated in crimes that one did not personally commit. When Primo Levi locates 'the same shame' in the soldiers who liberated Auschwitz and the prisoners who both witnessed and suffered outrageous violence in the camp, he attests to this capacity to feel responsible for crimes committed by others: not because prisoners and liberators have entered a 'zone of indistinction', nor because they are confused about who did what, nor even because of some masochistic 
desire to heap blame upon themselves, but rather from a feeling of justice, a feeling of remorse that these crimes even happened, and that they can never be undone. There is nothing puerile about this 'shame which the just man experiences when confronted by a crime committed by another' (Levi, 1988: 72-3). It is the basis for ethical and political resistance, and provides the only plausible, non-exclusive content for the term 'humanity'.

\section{The flush of shame: Agamben and Robert Antelme}

In order to develop this notion of a shame 'beyond guilt and innocence', Agamben refers to Robert Antelme's narrative about a young student from Bologna who is randomly singled out for execution by an SS officer on the march from Buchenwald to Dachau:

The SS continues, 'Du komme hier!' Another Italian steps out of the column, a student from Bologna. I know him. His face has turned pink. I look at him closely. I still have that pink before my eyes. He stands there at the side of the road. He doesn't know what to do with his hands. ... He turned pink after the SS man said to him, 'Du komme hier!' He must have glanced about him before he flushed; but yes, it was he who had been picked, and when he doubted it no longer, he turned pink. The SS who was looking for a man, any man, to kill, had found him. And having found him, he looked no further. He didn't ask himself: Why him, instead of someone else? And the Italian, having understood it was really him, accepted this chance selection. He didn't wonder: Why me, instead of someone else? (Cited $R A$ : 103; see HR: 231-2)

The student is singled out for no reason; he is 'innocent', but he will be executed as if he were guilty of the most heinous crime. Why does he blush, and what does this blush signify? For Agamben, the blush attests to a shame that outlives the student himself: the shame of being made to bear witness to his own desubjectification and death. Agamben comments: 'In shame, the subject thus has no other content than its own desubjectification; it becomes witness to its own disorder, its own oblivion as a subject. This double movement, which is both subjectification and desubjectification, is shame' (RA: 106). Agamben contrasts the survivor guilt he has criticized in Levi and Bettelheim with this shame before death, shame 'for having been haphazardly chosen - himself and no one else - to be killed. In the camps, this is the only sense that the expression "to die in the place of another" can have: everyone dies and lives in place of another, without reason or meaning; the camp is the place in which no one can truly die or survive in his own place' (ibid.: 104). For Agamben, dying in the place of another means dying an improper death, singled out at random for no reason. It could have been anyone - it could have been Antelme himself - but for no good reason, Antelme survived and the student was murdered. There is no point feeling guilty for this survival because it is neither deserved nor undeserved; at best, we can acknowledge our own exposure to death, our own double movement of subjectification and desubjectification.

If 'shame is truly something like the hidden structure of all subjectivity and consciousness', as Agamben argues ( $R A: 128)$, then it is not only the student from Bologna who is 'summoned by an irrefutable order to be present at [his] own 
defacement' (ibid.: 106), but each of us insofar as we both appropriate being and are expropriated by it:

The self is what is produced as a remainder in the double movement - active and passive - of auto-affection [in Kant, read through the lens of Heidegger (RA: 109-12)]. This is why subjectivity constitutively has the form of subjectification and desubjectification; this is why it is, at bottom, shame. Flush is the remainder that, in every subjectification, betrays a desubjectification and that, in every desubjectification, bears witness to a subject. (ibid.: 112)

Agamben interprets the pink flush of the student's face as a sign of shame, and he interprets shame as the fundamental structure of subjectivity. For him, the student's flush is 'a new ethical material' which functions as a 'mute apostrophe flying through time to reach us, to bear witness to him' ( $R A$ : 104). But what does this witness teach us, and in what sense does it constitute a new ethical material?

For Agamben, the student's flush bears witness to the inhuman in the human, the impropriety of the proper, the desubjectification of every subject - to that which can neither be evaded nor assumed. This flush is material because it emerges as an affective and even physiological response; it occupies a zone in between the physical and the psychical, zoe and bios. Like language, it refers to some sort of subjective interiority, someone who has turned pink for a reason (which may remain inchoate, but nevertheless involves the apprehension of a meaningful situation or provocation). But unlike language, the flush arises involuntarily, as a physiological reaction to a situation apprehended as meaningful. The flush is an ethical material because, for Agamben, the ethos of human subjectivity is this in-between zone of unassumable life and/or language which leaves a trace of the inhuman in the human, be it the animality of bodily life or the impersonal structures of language, or even the trace of being itself (or of death, which individuates our being). Ethics for Agamben means bearing witness to this inhuman in the human, this unassumable remnant that both makes subjectivity possible and also burdens it with something the subject cannot fully integrate or appropriate. This witness resists the biopolitical gesture of exploiting the gap between bios and zoe, producing both sovereign power and bare life, the German and the Jew, the proper and the improper, the human and the abject. Only by bearing witness to the inhuman in the human - to the 'strangers' in ourselves - would we be able to address and avert the violence of radical dehumanization epitomized by Auschwitz.

The question is whether Agamben's analysis of the problem posed by Auschwitz is correct, and whether his account of witnessing the inhuman in the human is an adequate response to this problem. More precisely, the question is whether the 'unassumable' remnant to which the flush bears witness is the inhuman in the human, or responsibility for the other human, as I will argue. This responsibility for the other need not imply a determinate concept of the human as a special kind of subjectivity bearing certain properties (such as reason, language, compassion and so forth), and it may involve a greater degree of impersonality than we often assume. In my view, the inhuman is an inadequate term for that which cannot be assumed by the subject, precisely because it fails to provide enough resistance to dehumanization. At certain moments of Agamben's analysis, the 
'new ethical material' of the inhuman becomes practically indistinguishable from radical dehumanization. This is the 'zone of indistinction' or point of indifference between ethics and oppression - which arises in all of Agamben's work on biopolitics. Agamben's claim that the student's blush bears witness to the structure of subjectivity as such, rather than in the extreme situations of the camp and the death march, risks both decontextualizing the Bolognese student's murder (since not all of us are forced to bear witness to our desubjectification in quite so brutal a manner), and also identifying subjectivity with the empty individuation of humiliation rather than the ambiguous relationality of shame, as if political oppression were the fundamental human condition.

Agamben calls the blush a 'mute apostrophe' that bears witness on its own, as the inhuman in the human, to the subjectivity of the student. But is there not another witness, without whom this flush would not even exist for us? Robert Antelme, survivor of Buchenwald, Gandersheim and Dachau, bears witness to the student's blush, in a language which both enables him as a subject and consigns him to impersonal structures which cannot be fully assumed. Without Antelme's testimony, the student from Bologna dies alone, and the pink flush on his face disappears. Nothing, not even his shame, outlives him without this testimony of another subject. But his affective response to the gesture of being singled out for murder did leave its mark on Robert Antelme, whose writing leaves its mark on any reader who encounters the book. Antelme bears witness to the student's ambiguous response, which resists any definitive interpretation as shame or fear, protest or assent, but at the same time demands a response from anyone who witnesses it. With his testimony, Antelme not only saves the student's blush from oblivion; he also bears witness to the multiple relations between the student and himself, himself and the reader, the reader and the student, and even between the student and the SS officer. If there is an anonymity or impersonality here, it is not the impersonality of being, but rather of these relations which are as human as they are impersonal - impersonal because they do not refer to any particular person, nor even to the form of a person, but to the interpersonal, to the relations of responsibility which belong to no one, but are the only plausible source of meaning for 'the human'.

Building on this critique of Agamben and rereading this passage in the context of Antelme's own narrative, we can now formulate an alternative interpretation of the ethical and political significance of the student's blush.

\section{Rereading Antelme}

Antelme's book The Human Race (1992; first published in 1957) gives an account of his experience as a French political prisoner in Buchenwald, Gandersheim and Dachau in 1944-5. In his citation of Antelme's text concerning the Bolognese student, Agamben excises several key passages which I would now like to restore and interpret. Immediately after the ellipses in the middle of Agamben's citation, after the sentence, 'He doesn't know what to do with his hands ...' Antelme continues: 'He seems confused [Il a l'air confus]' (HR: 231; translation modified from 'He seems embarrassed'). This sentence is followed immediately by a reflection on the importance to prisoners of remaining invisible to the SS. Antelme removes his glasses in order to blend in with the crowd; he moves closer to the center of the column of marching prisoners, explaining: 
Above all, our eyes must not meet the eyes of the SS.

Eyes that express feeling, that suggest the capacity for judgment - that's what makes them want to kill. We must be bland, lackluster, already inert. To have eyes is for each one of us to be in danger. (HR: 231)

To have eyes is already to express one's resistance to dehumanization; in order to survive, one must blot out the expressive capacity of one's face, miming an inert death-in-life. Immediately after this reflection, Antelme reports the sound of gunshots in the forest: the random execution of the student from Bologna, along with other Italian prisoners who had been selected from the column. At this point, Agamben's citation of the text resumes with Antelme's meditation on the significance of the student's flush, concluding with the phrase, 'He didn't wonder: Why me, instead of someone else?' (RA: 103; HR: 232). Antelme's text continues:

The guy next to him must have felt half of his body stripped naked.

We don't talk. We each try to be ready. Each is afraid for himself, but we have probably never felt such solidarity with each other, never felt so replaceable by absolutely anybody at all. We prepare ourselves. That consists in repeating, 'We're going to get it small group by small group'; in seeing ourselves standing in front of the machine pistol. Ready to die - that, I think, we are; ready to be chosen at random for death - no. If the finger designates me, it shall come as a surprise, and my face will become pink, like the Italian's. (HR: 232)

In this passage, Antelme attests to a radical substitution of any prisoner for any other, a solidarity strengthened rather than diminished by the random designation of some, but not others, for annihilation. On one hand, the student from Bologna is singled out at random for death, and his face turns pink. We cannot know what the student is feeling - is he confused, embarrassed, surprised, terrified? Even with this opacity of feeling, the structure of being singled out for execution echoes the structure of empty individuation in humiliation. The gesture of the SS officer singles out the student as nothing and no one, in a way that allows him neither to escape this empty individuation nor to assume it - for there is nothing to be assumed. The gesture of being singled out to die gives the student nothing to be, and leaves him no alternatives to annihilation. And yet, on the other hand, his affective response to this gesture immediately makes an impression on his fellow prisoners, and in so doing it already begins to exceed and contest the structure of humiliation. Just as the student is singled out for death, Antelme speculates that his closest neighbor also feels 'half of his body stripped naked'. It could have just as easily been him - but it wasn't. One man will be murdered, the other will survive at least another moment. The randomness of this selection produces a strange feeling of solidarity among the prisoners, a feeling of being utterly replaceable, of each murder being potentially one's own. This is not the empty individuation of humiliation, nor the heroic individuation of Heidegger's Being-towards-death, in which each Dasein is consigned to its own solitary, unsharable death. Rather, what emerges in this feeling of solidarity is a relationship to the death of the Other as if it were one's own, a feeling of being stripped 
naked by the violence which I was spared, but my neighbor was not, a feeling of substitution for the Other in the midst of remaining oneself. ${ }^{7}$

Antelme says that he is prepared for death, but not for being singled out at random for death; if it happens to him, 'it shall come as a surprise, and my face will become pink, like the Italian's'. There is a significant difference between dying and being singled out for political murder; and the blush functions as a material sign of this difference, this irreducibility of murder to death. And so, while I agree with Agamben that the student's blush is 'like a mute apostrophe flying through time to reach us, to bear witness to him' (RA: 104), I disagree about how to interpret this witness. For Agamben, the student's blush bears witness to the inhuman in the human, the desubjectification of subjectification, and to the death that one can neither assume nor escape, but which the student was forced to witness. But if we restore Antelme's narrative to its context, a different interpretation becomes possible, one which does not reduce the student's life and death to a moment of empty individuation. On my interpretation, the student's blush signifies beyond that moment of desubjectification, pointing to an excess of relationality which cannot be contained or reduced, not even by the SS officer who selects this student from out of the crowd and condemns him to death. The student's blush survives his death, not as an inhuman remainder of the human, but rather as a sign of interhuman relations.

Antelme's own experience of hearing his name called out during roll call underscores this sense in which even the mechanism of empty individuation produces an excess of relationality which it cannot contain or suppress, and which provides an opening for further resistance. A roll call is taken in the middle of the night before he and his fellow prisoners are forced to march from Buchenwald to the train station that would take them to Gandersheim for hard labour and starvation:

They count. A Lagerschutz calls out the names, butchering them. In among them, amidst Polish and Russian names, is my name. Laughter when my name is called, and I reply 'Present.' It sounded outlandish in my ear; but I'd recognized it. And so for one brief instant I had been directly designated here, I and no other had been addressed, I had been specially solicited - I, myself, irreplaceable! And there I was. Someone turned up to say yes to this sound, which was at least as much my name as I was myself, in this place. And you had to say yes in order to return into the night, into the stone that bore the nameless face. Had I said nothing, they would have hunted for me, and the others would not have left until I was found. They would have had a re-count, they would have seen that there was one who didn't say yes, one who didn't want that him to be him. Then, having found me, the SS would have worked me over so as to make it clear to me that here being me really meant being me, and so as I'd have the logic of it good and straight in my head: that, around here, I was damned well I, and that this nothing that bore the name that had been read out was damn well me. (HR: 21)

Antelme's mispronounced name is a trap which fixes him in place as one of those whose names are called in the middle of the night, who are counted, who are not free to say no or to remain silent, and who grow to resemble each other more and more as their hair is shorn, their clothes are replaced by striped uniforms, and their cheeks become hollow and grey. This is the structure of humiliation: to be singled out as no one or nothing, in this case with a name that one can neither escape nor claim as one's own. 
But it is also - if only for a brief instant, and only from his own perspective - an escape, an indirect and unintended affirmation of his irreplaceable singularity. The Lagerschutz was forced to struggle with Robert Antelme's name, his name and no other, if only in order to count him and control him. Even in a situation of near-total domination, Antelme retains this minimal power: to make the SS pronounce his name (however badly), to make them acknowledge his difference from the other prisoners in order to count him as one. ${ }^{8}$ Even the interminable 'Alle Scheisse! Alle Scheisse!' of the SS officers is addressed to someone; even the roll call speaks the prisoners' names to them, listening for their answer; even the command, 'Du, komme hier!' is barked to someone. Even in singling someone out for murder, that person is addressed; a vocative dimension, or what Levinas would call the 'saying', is opened and cannot be closed even through the murder of the addressee (see Levinas, 1998: 5-8). This may seem like a small consolation, especially to the one who is murdered - and I do not wish to suggest that this 'saying' alone counters the force of the random death sentence. But in reflecting on how resistance to domination and dehumanization takes root, I think it makes sense to start here, at the point where the violence of domination trips over itself, encountering an obstacle which prevents it from ever completing its project of totalization: namely, the alterity of the Other and the human plurality which it implies. This alterity can be violated, denied, degraded - but it can never be utterly destroyed, because it cannot help addressing itself to the Other whom it seeks to annihilate.

Antelme and his fellow prisoners are both desubjectified by their names - forced to recognize themselves in a mangled form of their own identity - and also indirectly and inadvertently subjectified, acknowledged in their singularity, or at least in their distinction from all the others, in a way that ultimately thwarts the total desubjectification to which they are exposed. But this double process of desubjectification and subjectification does not unfold according to the logic that Agamben describes in Remnants of Auschwitz; it does not happen in such a way that the inhuman settles out and bears witness to the human. Rather, the subjectification or singularization that Antelme describes occurs in spite of the project of desubjectification, at the limit where this project becomes incoherent, no matter how well-organized and well-executed it may be. In order to desubjectify or dehumanize you, they still have to single you out; and in singling you out, they undermine the very project of effacing your singularity. It is not an ontological connection between appropriation and expropriation that is brought to light here, but rather a political connection between oppression and resistance. The implication is that even the oppressor cannot help but affirm on some level, however indirect and unintentional, the resistance which he or she seeks to overcome. ${ }^{9}$

But there is one other movement which complicates what might otherwise seem like a 'double movement' of subjectification at the very moment of desubjectification. For, as Antelme explains, the mispronounced name is also a passage back into the anonymity of the night. As long as you say 'yes' when your name is called, you will not be singled out further; you will not be chased down in order to have your identity beaten into you. You may return to 'the stone that bore the nameless face'. The less you are noticed in the camps, the more you are able to slip back into the anonymity that will protect you from arbitrary violence, and the greater your chances of survival. This is why, at key moments of the narrative, Antelme removes the glasses that distinguish him from other prisoners, 
averts his eyes from Kapos and SS officers, and tries to blend into the crowd. To be seen is, for Antelme and his fellow prisoners, to be exposed to violence and even death. Just a few pages after Antelme's account of the student from Bologna, he reflects on relations of seeing and being seen in a way that bears directly on questions of testimony and solidarity. The men are being marched through a small German town in the early evening, a day after the Italian prisoners' execution:

Yesterday morning, while the guys were being killed, these people were strolling about like this, on these sidewalks. The butcher was weighing the meat ration. Perhaps a child was sick in bed, and his face was pink, and his worried mother was looking at him. On the road, the Italian's face turned pink; death slowly entered into his face and he didn't know how to behave, how to appear natural. The mother may be watching us go by now: prisoners. Five minutes ago they didn't know a thing about us. ... They're losing the war, their men are dying, the women are praying for them. Who sees them blown to bits by the shells, and saw those who'd just been machine-gunned, under the trees, in the Harz yesterday? Who sees the pink-faced little child in his bed and yesterday saw the pink-faced Italian on the road? Who sees the two mothers, the child's mother, and the Italian's mother, in Bologna, and these likenesses? But does not everyone have eyes?

So long as you are alive you have a place in all this and you play a role in it. Everyone here on the sidewalks, pedaling by on bicycles, looking at us, or not looking at us - has a part he's playing in this story. Everyone is doing something that relates to us. They may kick sick guys in the belly, or kill them, or force guys with the shits to remain closed up inside a church and then shoot them because they shit, or yell Alle Scheisse, alle Scheisse! for the millionth time, between them and us a relationship nevertheless exists that nothing can destroy. They know what they are doing, and they know what's being done to us. They know it as well as us. And they are. You are us. (HR: 235-6)

Antelme asks: Who sees, who will bear witness? And he answers: We all have eyes. No one is exempt from the responsibility to see, and even the refusal to see what is happening does not efface this responsibility or sever the relation of each human being to every other. In this passage, the pink flush of the student from Bologna detaches from its initial context and becomes transitive; it passes between the face of the student and the face of a child sick in bed, it sneaks behind enemy lines. This pink becomes a sign, not only of the student's affective response to being singled out for murder, but also of the relation between himself and everyone else who can see, everyone else who has both the capacity and the responsibility to bear witness, whether they are prisoners or civilians, young or old, men or women. ${ }^{10}$ The pink flush attests to the irreducible relationality of all subjects, even those who have been systematically desubjectified, in a way that demands responsibility whether or not one is personally guilty of a crime. The student's flush may be a physiological response to the humiliation of being singled out as nothing; but at the same time, it functions in Antelme's narrative as a sign of what Primo Levi calls 'the shame which the just man experiences when confronted by a crime committed by another' (Levi, 1988: 72-3). This shame is collectively shared in a way that does not rely on personal guilt; and yet, to take it out of the register of innocence and guilt altogether, removing it into an ontological realm, would efface the responsibility to which it commands 
each one of us. Rather than downplaying this collective responsibility, we need to emphasize and develop it, not as a generic response to an insoluble ethical problem, but as the condition for ethics as such.

Antelme's reflections on the irreducible relationality of all human beings close with this sentence: 'You are us.' It is not just that you see us from a distance, being marched through your quiet little town in the evening. You are us - which does not mean that you know anything about us, or could possibly understand what we have been through. And it does not necessarily mean that we are you, that the relations can be simply reversed without a profound change in significance. You are us in spite of what you know or don't know about us, because you are implicated in our suffering. It could have just as easily been you, and in a few days when the Allied forces roll through this town, it may very well be your house that is burnt, your son killed, your body tortured. What remains indestructible is this relation to the Other, and the responsibility to see or bear witness to both the singularity and the substitutability of every human being, to what Antelme calls the 'almost biological claim of belonging to the human race [espèce]' (HR: 6). ${ }^{11}$

\section{'A naked relation to naked life': Agamben and Maurice Blanchot}

In The Infinite Conversation (hereafter cited as IC), Blanchot articulates the main insight of Antelme's book: ' $m a n$ is the indestructible that can be infinitely destroyed' (cited $R A$ : 134; IC: 130). ${ }^{12}$ At the end of his chapter on shame, Agamben cites this passage, adding that "Blanchot misunderstands his own words when he sees infinite destruction as the place of "the human relation in its primacy," as the relation to the Other' (RA: 134). What Blanchot should have said, according to Agamben, is that 'the human being is the one who can survive the human being', the one who bears witness to its own desubjectification, like the student from Bologna (ibid.). For Agamben, the unthought significance of Blanchot's phrase is that 'the place of the human is divided because human being exists in the fracture between the living being and the speaking being, the inhuman and the human' (ibid.). But what if we took Blanchot at his word, that the site of the 'indestructible that can be (infinitely) destroyed' is the relation to the Other?

The plain meaning of Blanchot's text seems to be that, while torture and totalitarian domination can destroy individual human beings, nothing can destroy the relation to alterity. This is not because alterity is inherently stronger or more resilient than subjectivity, but rather because even the radical alienation of the subject - even that which makes me a stranger to myself - leaves this relation to otherness as a remainder. 'In affliction we approach the limit where, deprived of the power to say "I," deprived also of the world, we would be nothing other than this Other that we are not' (IC: 130). This indestructibility of the Other implies that even when the I is destroyed, even when its capacities and possibilities are utterly blocked, a relation and even a responsibility for the Other still remains: 'we no longer have the least chance of seeing ourselves relieved of ourselves or of our responsibility' (ibid.). The point of this reference to responsibility is not to heap yet another burden on the already-beleaguered self, but rather to suggest a site of resistance to the inexorable dehumanization which destroys the I: not in a radical egoism which determines to survive at all costs, since that desire to survive is precisely what is being exploited in torture, but rather in a relation to alterity which survives even 
the destruction of the I. For Blanchot - as for Levinas, who remains as one of the silent partners in this conversation ${ }^{13}$ - responsibility is not a burden but rather a way of 'getting out of being by a new path' (Levinas, 2003: 73), be it a way out of suffocating selfencumberment, or a way out of the endless destructibility of the I.

Agamben interprets Blanchot's claim that humanity is 'the indestructible that can be destroyed' on both an individual and a structural level, in a way that evades or eclipses the collective dimension of intersubjective relationality. For Agamben, Blanchot should have said that 'the human being is the one who can survive the human being' ( $R A: 134)$, i.e. the Muselmann who survives his or her own radical dehumanization. This interpretation applies destruction and indestructibility to the same being, uniting them in the same 'zone of indistinction'. But if we read Blanchot's claim in context, it seems much more plausible to interpret his claim on two different, non-reciprocal levels, such that the individual subject is destructible, but the collective subject (or intersubjectivity understood as a relation to alterity) remains indestructible. Blanchot locates the nexus of destructible subjectivity and the indestructible relation to alterity in affliction, which pushes bodily need to such an extreme point that it no longer refers to a personal will or desire to survive, but rather to the impersonal form of human relation:

When man is reduced to the extreme destitution of need, when he becomes 'someone who eats scraps,' we see that he is reduced to himself, and reveals himself as one who has need of nothing other than need in order to maintain the human relation in its primacy, negating what negates him. It must be added that need now changes; radicalized in the proper sense of this term, it is now no more than a need that is barren, without pleasure and without content: a naked relation to naked life where the bread that one eats answers immediately to the exigency of need, just as need is immediately the need to live. ... [W] hat we encounter in Antelme's experience, the experience of man reduced to the irreducible, is the radical need that relates me no longer either to myself or to my own self-satisfaction, but to human existence pure and simple, lived as lack at the level of need. And it is still no doubt a question of a kind of egoism, and even of the most terrible kind, but of an egoism without ego where man, bent on survival, and attached in a way that must be called abject to living and always living on, bears this attachment to life as an attachment that is impersonal, as he bears this need as a need that is no longer his own need proper but as a need that is in some sense neutral, thus virtually the need of everyone. 'To live,' as he more or less says, 'is then all that is sacred.' (IC: 133; emphases on 'naked relation ...' added)

Pushed to such an extreme relation of need, the subject of life is destroyed, the ego annihilated; one could say that the bios, or personal specificity, of the human being is stripped away. But a human relation nevertheless remains because, for Blanchot and Antelme, the human is not contained in the subject or ego, or even in bios, but in a relation to alterity that not even the extremity of need is able to destroy.

One can therefore say that when, through oppression or affliction, my relation with myself is altered and lost - making of me this foreigner, this unknown from whom I am separated by an infinite distance, and making of me this infinite separation itself - at this moment need becomes radical: a need without satisfaction, without value, that is, a naked relation to naked existence; but this need also becomes the impersonal exigency that alone bears the 
future and the meaning of every value or, more precisely, of every human relation. The infinite that is the movement of desire passes by way of need. Need is desire and desire becomes confounded with need. It is as though in nourishing oneself at the level of subsistence it is not I who am nourished; it is as though I received the Other [l'Autre], host not to myself but to the unknown and the foreign. (IC: 133; emphases added)

For Blanchot, the subject does not survive the affliction of radical need; but this does not mean that the subject is therefore made to bear witness to its own desubjectification. Rather, the one whose existence has been reduced to 'a naked relation to naked life' still attests to an irreducible relation to alterity, a hospitality for the Other who is foreign and unknown, an impersonal but human relationality that evades the bios/zoe distinction. While Agamben sees in bare life (literally, 'naked life' [nuda vita]) a Muselmann or homo sacer - the living dead, stripped of all meaningful relations to a human community - for Blanchot, the 'naked relation to naked life' reveals 'the human relation in its primacy', the bare form of relation to others. The subject reduced to naked life still has this source of resistance, this relation to alterity which is the minimal form of human community. Even the most radical domination - even that which utterly destroys the subject - does not destroy this bare form of human relation, this exposure to alterity without which there is no community. ${ }^{14}$ For Blanchot, community does not begin with a subject who is then linked up with other subjects, but rather with this relation to the Other which is prior to - and capable of surviving - the individual subject. What we end up with, even in the most extreme exploitation of the body's vulnerability, is not the inhuman in the human, but rather the still-human in the dehumanized, and so a basis for the sort of resistance that would rebuild support for an individuated subject. ${ }^{15}$ But if this is the case, then the bios/zoe distinction does not capture what is at stake in naked existence; in focusing on the tension between different aspects of the subject, it misses the significance of intersubjectivity. If the feeling of shame plays any productive role in social life, it is in highlighting this structure of intersubjectivity in which I become stuck to myself, or individuated, through the indestructible (but never unambiguous) exposure to others.

Blanchot's analysis begins with the relationality which survives even the most extreme affliction; but it does not end there. In order to move beyond the mere confirmation of indestructible relationality, we need to build solidarity in a community of those who have nothing in common, a community rooted in responsibility: 'that is, it must find in this injustice [of affliction] the point of departure for a common demand' where the affliction of one is recognized as 'an injustice committed against everyone' (IC: 134). ${ }^{16}$ Ultimately, the subject needs to re-enter a dialectical struggle with the powerful - not as an isolated individual, but as part of a collective subject, a proletariat of the afflicted. Blanchot emphasizes the importance of a 'double relation': both the impersonal human relation disclosed in radical need and affliction, and also the political relation of specific communities caught up in struggles of power and resistance. As Sarah Kofman writes in Smothered Words: 'By showing that the abject dispossession suffered by the deportees signifies the indestructibility of alterity, its absolute character, by establishing the possibility of a new kind of "we," it [Antelme's book] founds without founding - for this "we" is always already undone, destabilized - the possibility of a new ethics. Of a new humanism' (1998: 73). It also raises the possibility of a new theoretical 
language for biopolitics: a biopolitics of resistance rooted in the ethics of alterity. This biopolitics of resistance takes as its starting point an embodied, signifying relationality which crosses the distinction between bios and zoe rather than focusing on a zone of indistinction between them. For this post-Agambenian biopolitics, it is not a matter of finding a perfect, indissoluble unity of bios and zoe, or what Agamben calls at various points in his work 'happy life' or 'form-of-life' (RA: 24; Agamben, 1998: 188; Agamben, 2000: 2-12, 114-15). Rather, a resistant biopolitics must begin with an ethics of alterity - not with subjectivity, nor with the zone of indistinction between subjectification and desubjectification, but with the Other.

As Levi, Antelme and Blanchot teach us, life is never bare - not because bios cannot be separated from zoe, but because the relation to the Other cannot be destroyed. Even when reduced to a 'naked relation to naked existence', even when exposed to an unimaginable extremity of need and affliction, even when forced to steal from others in order to secure one's own survival, the subject retains a relation to alterity which provides a starting point, however minimal, for resistance. This relationality remains even when every relation to every particular other has been severed, and it remains even when the subject who would be in relation to others - the I, the ego - has been utterly destroyed. The subject may not be strong enough to survive the biopolitical machine; but humanity is not merely a collection of individual subjects. Humanity makes sense only as an irreducible relation to alterity which cannot be destroyed, not even through murder or mass extermination. As such, it retains a degree of resistance against everything that violates and exploits it: torture, poverty, humiliation, slavery, racism, and all the other ways that human beings have created to destroy one another.

\section{Notes}

1. For critiques of Agamben along these lines, see Mesnard (2004), Bernstein (2004), Mills (2004). For other critiques of Agamben's approach to shame, see Hutchinson (2008: 42-86) and Leys (2007: 157-80).

2. My analysis will focus mostly on Antelme, in part because I think his work has been relatively neglected, and in part because I think he makes the most eloquent case for a solidarity rooted in the irreducible relationality of embodied subjects, even when they are exposed to the most extreme humiliation and suffering.

3. He finds some limited textual support for this in a selective reading of Primo Levi. Levi writes that 'one must answer personally for sins and errors, otherwise all trace of civilization would vanish from the face of the earth' (cited RA: 95). Agamben interprets this to mean that 'Levi is perfectly convinced that it makes no sense to speak of collective guilt (or innocence) and that only metaphorically can one claim to feel guilty for what one's own people or parents did' (ibid.).

4. See Agamben's earlier work, Language and Death: The Place of Negativity (2006), for a fuller sense of his intellectual roots in Heideggerian ontology.

5. While it is true that other animals, especially social animals like dogs, seem to have access to something like a feeling of shame, I think it is important to read Bettelheim's claim in its context: not as an attempt to find some characteristic which absolutely distinguishes between humans and other animals, but rather as an analysis of how the survivor has managed to emerge 
from camps that were systematically organized to degrade, dehumanize and demoralize, with some sense of dignity and responsibility.

6. In this sense, I am departing from the conventional distinction between guilt and shame, which links guilt to what one has done and shame to who one is (for a more elaborate discussion of this distinction, see, for example, Williams [1993: 88-95, 219-23]). For me, shame is not just about subjectivity but intersubjectivity, or the doubling-up of self-relation and relation to others that we find in Sartre and Sedgwick.

7. This reading is heavily influenced by Levinas' concept of substitution, elaborated in Otherwise than Being (1974: 99-129), and also by his concept of 'dying-for' the Other (1998: 207-17). Dying-for does not refer merely to the martyr's gesture of self-sacrifice; it is already here in this feeling of being affected by the death of the Other to the point of feeling 'replaceable by absolutely anybody at all'. For reasons of brevity and focus, I leave aside a fuller discussion of Levinas in this context, as well as a critical analysis of Agamben's reading of Levinas' account of shame in On Escape (RA: 104-6). In short, I think Agamben overlooks Levinas' more radical insights into the ethical significance of shame by focusing on his earlier ontological account of shame, and that even in his reading of On Escape, Agamben misconstrues Levinas' analysis in the name of 'deepen[ing]' it (RA: 105).

8. Elsewhere in the narrative, Antelme reflects further on this power, arguing that even the camp's perverse commandment, 'Thou shalt not be', 'cannot stop us from exerting our power' (HR: 74, 75). When a German civilian approaches Antelme and a few other prisoners in order to shake hands with them covertly, Antelme observes: 'We had become accomplices. But he hadn't so much come to encourage us as to seek reassurance himself, to obtain a confirmation. He came to share in our power. Against that handshake there was nothing that could prevail, neither the barking of thousands of SS troops nor the whole apparatus of ovens, dogs, and barbed wire, nor famine, nor lice. To no one as well as to us could the SS soul open itself fully. But for his part this other German had perhaps not felt for years so restored to himself as he did in shaking hands with one of us' (HR: 75).

9. As Lars Iyer (2003) argues, 'the non-voluntary opening to the deportee, to the Other, entails a displacement of the structure of the identity of the SS, opening it up, or rather, revealing the opening that was already there. It is therefore impossible for the SS to maintain the organisation of an inside that would be symmetrical and commensurable with an outside (the Jew, the Other)' (2003: 5).

10. In her critique of Agamben's reading of Antelme, Ruth Leys writes: 'The move from the Italian student to the sick child is crucial for Antelme in this regard. Pink, rose, emerges as the most vivid figure that Antelme can propose for the absolute similarity or likeness of human beings. It cannot be tied to any specific emotion [like shame]. ... All we are entitled to say is that in these pages pink appears to be an expression of a threatened aliveness or vitality' (Leys, 2007: 178).

11. John Dalton writes: 'Yet for Antelme, the vision of indivisible oneness is, resolutely, not an appeal to alterity. If, as [Sarah] Kofman suggests, we are indeed afforded the responsibility to think a new ethics and a new humanism in response to Antelme's experience, we need to then think how Antelme's understanding of humanity comes first not from a positive concept of the human, but is a response to horror, and finds within its outrage a political voice' (Dalton, 2005: 162). But on my reading, alterity does not fill the concept of humanity with a 'positive content'; rather, it articulates the form of humanity as an irreducible relationality 
out of which subjects emerge, rather than a collection of subjects gathered under a common concept.

12. This is actually a misquotation; the word 'infinitely' does not appear in Blanchot's text (see IC: 130). Perhaps Agamben was thinking of The Writing of the Disaster, in which Blanchot writes: 'Human weakness, which even affliction does not divulge, penetrates us on account of our belonging at every instant to the immemorial past of our death - on account of our being indestructible because always and infinitely destroyed' (Blanchot, 1995: 30).

13. Blanchot's essay, 'The Indestructible', contains two parts: 'Being Jewish' (IC: 123-30) and 'Humankind' (ibid.: 130-5, his reading of Antelme). But it was originally published together with 'The Relation of the Third Kind: Man without Horizon' (ibid.: 66-74). All three parts are strongly influenced by Levinas' account of alterity, relation without relation, and the universal singularity of Judaism.

14. Throughout this discussion, I focus on the interhuman community. Antelme bases his claim to humanity (and the impossibility of dehumanization) not on the possession of a special faculty or power, such as reason or language, but rather on an 'almost biological claim of belonging to the human race' (HC: 5). He argues: 'we are unable to become either animals or trees' (ibid.: 219); the executioner 'can kill a man, but he can't change him into something else' (ibid.: 220). This impossibility of becoming anything but human could form the basis of a nonanthropocentric claim to humanity, one that resists defining the human in opposition to the non-human animal, while still providing grounds for resistance against dehumanization.

15. Blanchot's imaginary interlocutor responds that, while this may be true, the irreducible relation to another confirmed by need does not announce victory or salvation for the afflicted, but only an incomplete victory for the powerful. More than just need is required for the afflicted to find any kind of relief. 'For such a movement to begin truly to be affirmed, there must be restored - beyond this self that I have ceased to be, and within this anonymous community - the instance of a Self-Subject: no longer as a dominating and oppressing power drawn up against the "other" that is autrui, but as what can receive the unknown and the foreign, receive them in the justice of a true speech' (IC: 134).

16. A moving example of this substitutability of need and affliction can be found in Marguerite Duras' narrative, La Douleur (1986), in which she recounts her experience waiting for Antelme, who was then her husband, to return from Dachau: 'You don't exist anymore in comparison with his waiting. More images pass through your head than there are on all the roads in Germany. Bursts of machine gun for every minute inside your head. And yet you're still there, the bullets aren't fatal. Shot in transit. Dead with an empty stomach. His hunger wheels around in your head like a vulture. You can't give him anything. You can always hold out a piece of bread in the void. You don't even know if he still has need of bread. You buy honey, sugar, pasta. You say to yourself, If he's dead I'll burn the lot. Nothing can help the way his hunger burns you. People die of cancer, of car accidents, but no, they don't die of hunger, they're finished off first. What hunger has wrought is completed by a bullet in the heart. I'd like to give him my life. I can't even give him a bit of bread' (1986: 34). For a more skeptical reading of this sense of community in Blanchot's essay, see Fynsk (2005).

\section{Bibliography}

Agamben, Giorgio (1998) Homo Sacer: Sovereign Power and Bare Life, trans. D. Heller-Roazen. Stanford, CA: Stanford University Press. 
Agamben, Giorgio (2000) Means without End: Notes on Politics, trans. V. Binetti and C. Casarino. Minneapolis: University of Minnesota Press.

Agamben, Giorgio (2004) The Open: Man and Animal, trans. K. Attell. Stanford, CA: Stanford University Press.

Agamben, Giorgio (2005a) Remnants of Auschwitz: The Witness and the Archive, trans. D. HellerRoazen. New York: Zone Books.

Agamben, Giorgio (2005b) State of Exception, trans. K. Attell. Chicago, IL: University of Chicago Press.

Agamben, Giorgio (2006) Language and Death: The Place of Negativity, trans. K. Pinkus. Minneapolis: University of Minnesota Press.

Antelme, Robert (1992[1957]) The Human Race, trans. J. Haight and A. Mahler. Evanston, IL: Marlboro Press.

Bernstein, J. M. (2004) 'Bare Life, Bearing Witness: Auschwitz and the Pornography of Horror', Parallax 10(1) (January-March): 2-16.

Blanchot, Maurice (1993) The Infinite Conversation, trans. S. Hanson. Minneapolis and London: University of Minnesota Press.

Blanchot, Maurice (1995) The Writing of the Disaster, trans. A. Smock. Lincoln, NB and London: University of Nebraska Press.

Dalton, John (2005) “"Man is the Indestructible”: Blanchot's Obscure Humanism', Colloquy: text theory critique; accessed 20 November 2008, @: www.arts.monash.edu.au/others/colloquy/ issue 10/dalton.pdf

Duras, Marguerite (1986) La Douleur, trans. B. Bray. London: William Collins.

Fynsk, Christopher (2005) 'Blanchot's "The Indestructible"”, in Leslie Hill, Brian Nelson and Dimitri Vardoulakis (eds) After Blanchot: Literature, Criticism, Philosophy. Newark: University of Delaware Press.

Hutchinson, Phil (2008) Shame and Philosophy. Basingstoke, Hants: Palgrave Macmillan.

Iyer, Lars (2003) 'Movement and Testimony: Suffering and Speech in Blanchot and Antelme', j_spot: Journal of Social and Political Thought 5; accessed 5 November 2008, @: http:// www.yorku.ca/jspot/5/liyer.htm\#_edn36

Kofman, Sarah (1998) Smothered Words, trans. M. Dobie. Evanston, IL: Northwestern University Press.

Levi, Primo (1988) The Drowned and the Saved, trans. R. Rosenthal. New York: Summit Books.18\#Levinas, Emmanuel (1998) Otherwise than Being, or Beyond Essence, trans. A. Lingis. Pittsburgh, PA: Duquesne University Press.19\#Levinas, Emmanuel (2003) On Escape, intro. and annotated Jacques Rolland, trans. B. Bergo. Stanford, CA: Stanford University Press.

Leys, Ruth (2007) From Guilt to Shame: Auschwitz and After. Princeton, NJ and Oxford: Princeton University Press.

Mesnard, Philippe (2004) 'The Political Philosophy of Giorgio Agamben: a Critical Evaluation', trans. C. Guiat, Totalitarian Movements and Political Religions 5(1) (Summer): 139-57.

Mills, Catherine (2003), 'An Ethics of Bare Life: Agamben on Witnessing', borderlands 2(1); accessed 18 November 2008, @: http://www.borderlands.net.au/vol2no1_2003/mills_agamben. html

Mills, Catherine (2004) 'Agamben's Messianic Politics: Biopolitics, Abandonment and Happy Life', Contretemps 5: 42-62. 
Murphy, Ann (2004), 'The Political Significance of Shame', borderlands 3(1); accessed 1 November 2008, @: http://www.borderlands.net.au/vol3no1_2004/murphy_shame.htm

Sartre, Jean-Paul (2003) Being and Nothingness, trans. H. Barnes. London and New York: Routledge.

Sedgwick, Eve Kosofsky (2003) Touching Feeling: Affect, Pedagogy, Performativity. Durham, NC and London: Duke University Press.

Williams, Bernard (1993) Shame and Necessity. Berkeley: University of California Press. 